\title{
集光レーザーの光圧によるタンパク質結晶成長制御
}

\author{
杉山 輝樹 ${ }^{1,2}$, 柚山 健一 ${ }^{1, \dagger}$ \\ 1台湾国立交通大学 応用化学系 ( 330010 台湾新竹市大学路1001) \\ 奈良先端科学技術大学院大学物質創成科学研究科 ( $\bar{T} 630-0192$ 奈良県生駒市高山町8916-5)
}

\section{Laser Trapping-Controlled Crystal Growth of Protein}

\author{
Teruki SUGIYAMA ${ }^{1,2}$ and Ken-ichi YUYAMA ${ }^{1, \dagger}$ \\ ${ }^{1}$ Department of Applied Chemistry, National Chiao Tung University, 1001 Ta Hsueh Rd., Hsinchu 30010, Taiwan \\ ${ }^{2}$ Graduate School of Materials Science, Nara Institute of Science and Technology, \\ 8916-5 Takayama-cho, Ikoma, Nara 630-0192, Japan
}

(Received January 10, 2017)

\begin{abstract}
We present laser trapping-controlled crystal growth of protein, hen egg-white lysozyme (HEWL). A continuous-wave near-infrared laser beam of $1064 \mathrm{~nm}$ is focused at a point $10 \mu \mathrm{m}$ away from the generated HEWL crystal. Laser trapping of HEWL liquid-like clusters in solution firstly forms a millimeter-sized highly concentrated domain, inside which the crystal growth of the specific target crystal is realized and controlled. At the beginning of the irradiation, the crystal growth rate is extremely suppressed compared to that in spontaneous crystal growth, while it is enhanced by the continuous irradiation. The suppress and the enhancement of crystal growth rate can be controlled by changing laser power and polarization direction. The dynamics and mechanism of this unique crystal growth is discussed from the viewpoint of large, stable domain formation consisting of the HEWL liquid-like clusters and by considering the rigidity and anisotropy of the molecules/clusters in the domain.
\end{abstract}

Key Words: Laser trapping, Crystal growth, Protein, Dense cluster domain

\section{1. 緒 言}

光圧の存在は, 1871年にMaxwellによって理論的に導 かれ，1901年にLebedev，1903年にはNicholsらにより実 験的にその存在が実証された ${ }^{1,2)}$. 当時光圧は非常に微 弱な力であり実用には程遠かったが，1960年のレーザー の発明により現実的なものとなっだ².1970年にAskinは 単一のマイクロ粒子の両側からダブルレーザービームで 挟み込むことにより粒子を捕捉することに成功した ${ }^{4)}$. その後，レーザーを非常に強く集光することにより，シ ングルビームでも単一の粒子捕捉が可能であることを示 した ${ }^{5)}$. この成功以来, 集光レーザーの光圧は液中で非 接触に捕捉, 操作する技術として種々研究領域で採用さ れ，特にマイクロサイズの細胞の捕捉やその操作技術と して発展してきた。1990年代, 増原らにより光圧の化学 領域への応用が積極的に行われ, 高分子, 無機化合物, 金属ナノ粒子などの捕捉及びその捕捉ダイナミクス, メ カニズムの解明が行われてきた ${ }^{6-8)}$. 著者らは2006年よ り光圧を結晶化学へと応用する研究をはじめ, 2007年に
アミノ酸であるグリシンの光圧による結晶化に世界で初 めて成功した9)。著者らはこの現象をレーザー捕捉結晶 化と呼んでいる.

さらに2009年には光圧によるグリシンの結晶成長制御 の実験にも成功した ${ }^{10)}$ ，本実験では，まずグリシン過飽 和溶液を初期溶液とし, 自然に結晶が析出するのを待 つ. 結晶析出後, 溶液は飽和濃度へと漸近的に近づき, 最終的には溶液全体が平衡状態に達し, 見かけ上の結晶 成長は止まる。その後，光圧を溶液中の結晶のエッジか ら約 $20 \mu \mathrm{m}$ 離れたところに作用させると, 結晶はレー ザーを照射するとすぐに集光点の方向に向かって成長し 始める。 この時, 集光点の大きさは約 $1 \mu \mathrm{m}$ 程度と見積 もられるため, 光圧が直接結晶に作用することはない. その後，レーザー照射を止めるか，または成長している 結晶のエッジがレーザーの集光点に達すると結晶成長は 停止する，当時はこのメカニズムを説明することができ ず，集光点で生成した高濃度凝集体が，対流等に起因し た物質移動により結晶のエッジに達し, 結晶成長を誘起 しているのではないかと推察していた。詳細は後述する

\footnotetext{
†現所属: 北海道大学電子科学研究所 ( $\overline{0} 001-0020$ 北海道札幌市北区北20条西10丁目)

${ }^{\dagger}$ Present address: Research Institute for Electronic Science, Hokkaido University, N20W10, Kita-Ward, Sapporo, Hokkaido 001-0020
} 
が，その後の研究から集光点及びその周辺でミリメート ル程度の巨大高濃度クラスター集合体を形成しているこ とが分かり ${ }^{11,12)}$, 現在では高濃度クラスター集合体の高 い分子・クラスター濃度に起因して結晶成長が達成され たと考察している。このような光圧による巨大高濃度ク ラスター集合体形成は，タンパク質であるニワトリ卵白 リゾチームの場合においても観察されることが分かって いる ${ }^{13,14)}$.

本稿では，この光圧により生成した巨大高濃度クラス ター集合体形成をタンパク質の結晶成長制御に応用した 研究結果について概説する。本研究の研究戦略の概略図 をFig. 1 に示す。まずターゲットとなるタンパク質の過 飽和溶液を調整し，タンパク質結晶化が自然に誘起され るのを待つ。析出した結晶から集光点の大きさ（通常 1 ミ クロン程度)に比べ十分に離れた場所へ光圧を作用させ る。レーザー照射により巨大高濃度クラスター集合体が 生成し，対象結晶はその内部に位置するようになる。高 濃度クラスター集合体内の分子の濃度や配列を集光レー ザーの強度や偏光方向によって最適化し結晶成長を制御 する. 本研究結果の一部は既にレーザー研究において紹 介済みであるが ${ }^{12}$, その後本研究は飛躍的な進歩を遂 げ，その成長メカニズムに関する多くの新しい知見を得 ることに成功している

\section{2. 実 験}

\section{1 サンプル作製}

本実験ではニワトリ卵白リゾチームの結晶を対象と し，光圧による結晶成長の制御を行った。レーザー照射 による集光点での温度上昇を避けるため, 溶媒として重 水を使用した。集光点における温度上昇は，既に報告さ れている実験結果を参考にすると ${ }^{15)}$, 多くても5度程度 であると見積もられる。

リゾチームの粉末サンプルを重水酢酸塩緩衝液に溶か しこれを母液とした $(80 \mathrm{mg} / \mathrm{mL})$ 。この母液に6.0\%の塩 化ナトリウム重水溶液を等量加えサンプル溶液とした （リゾチーム濃度, $40 \mathrm{mg} / \mathrm{mL}$; 塩濃度, $3.0 \%$ ； pD值， $5.1 ）$. ハンドメイドのシリコンチャンバー $(F i g .2(\mathrm{a}))$ を顕微鏡 ステージに置き, サンプル溶液 $40 \mu \mathrm{L}$ をチャバー内に

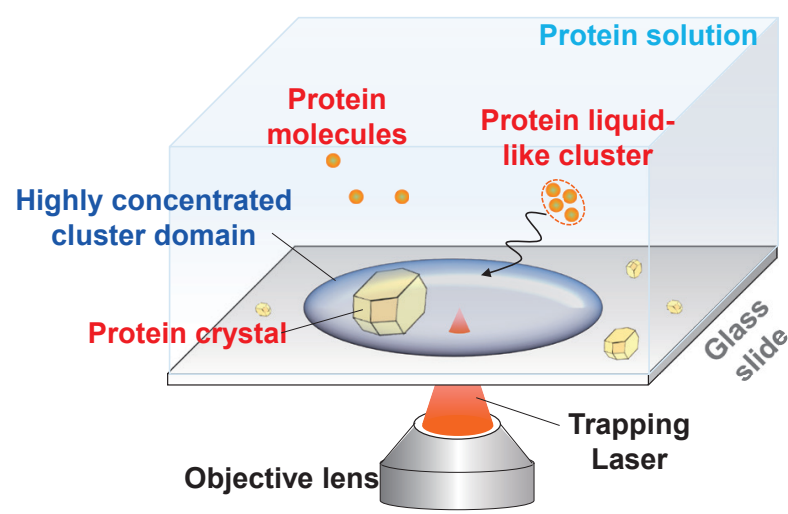

Fig. 1 Illustration of our strategy of laser trapping-controlled protein crystal growth. (a)

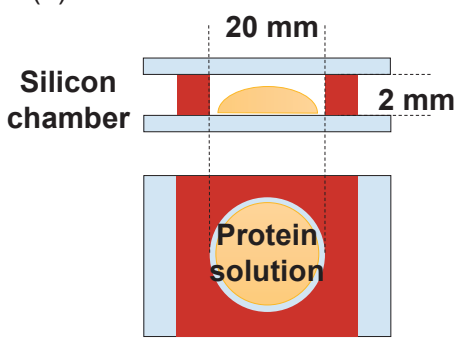

(b)

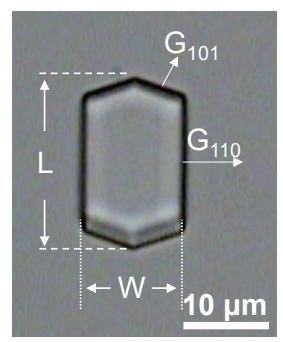

Fig. 2 (a) Schematic illustration of a silicon chamber used in this work, and (b) external appearance of tetragonal HEWL crystal observed from the direction of the (110) face.

滴下した。40分から1時間後には自然結晶化が誘起され， チャンバー内に2，3個の正方晶リゾチーム結晶が観察さ れた (Fig. 2(b))。得られた結晶の縦方向の長さ $(L)$ が 10 $-15 \mu \mathrm{m}$, さらに縦横比 $L / W$ 值が $1.5 \pm 0.1$ になった場合の み続く光圧実験の初期結晶として使用した。 サンプルに よる成長速度のばらつきを抑えるため, ターゲットとな る結晶の生成後, さらに40 $\mu \mathrm{L}$ のンプル溶液を注意深 く加え合計 $80 \mu \mathrm{L}$ になように調整した。加えて、溶液 の厚さが300 実験を開始した。

\section{2 実験光学系}

本実験で使用した光学系をFig. 3 に示す。光圧捕捉用 光源として直線偏光の連続発振近赤外レーザーを使 用し，対物レンズ $(\mathrm{NA}=0.90)$ を用いて上述したチャ ンバー内のサンプル溶液に集光した。集光点は自然析出 したリゾチーム結晶の(110)面から10 $\mu \mathrm{m}$ 離れた地点, かつ下部のカバーグラスから $3 \mu \mathrm{m}$ 上部にセットした。 また，直線偏光の方向は半波長板の角度を変えることに より調整し，その偏光方向は結晶の(110) 面(側面)に対 して垂直及び平行になるようにした(Fig. 3 左上図参 照)。レーザー光強度は対物レンズ通過後に $1.1 \mathrm{~W}$ になる ように調整した。この時の集光点でのレーザーのパワー 密度は約 $100 \mathrm{MW} / \mathrm{cm}^{2}$ 程度と見積もられる。レーザー照

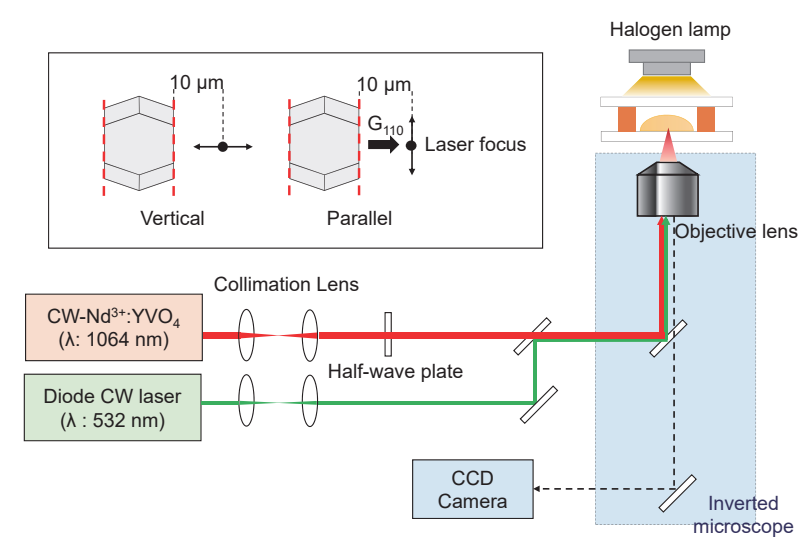

Fig. 3 Optical setup for laser trapping experiments with the illustration of the polarization direction of a linearly-polarized trapping laser to (110) face of HEWL tetragonal crystal. 
射時間は30分に固定した，更に，532 nmのレーザーを 光圧用光源と同軸で顕微鏡に導入し, 集光点の位置確認 やサンプル溶液の厚さ測定用として用いた。レーザー照 射及び未照射の結晶成長挙動はCCDカメラを用いて観 察された。すべての実験は室温25度の条件のもと行われ た。

\section{3 結晶成長速度の算出法}

本実験で用いたサンプルの溶液条件では，常に正方晶 系のリゾチーム結晶が析出する。そのリゾチーム結晶を (110)面から見た結晶形状をFig. 2(b)に示す。結晶は12 の結晶面から構成され，8つの(101) 及び4つの (110) 面を 有する。よって, リゾチーム結晶の見た目の形状はこ の2種類の結晶面の相対成長速度により決定される。 (101) 面の結晶成長速度を $G_{101}$, (110) 面の成長速度を $G_{110}$ とすると，それぞれの成長速度は下記の式によって 算出される ${ }^{16)}$.

$$
G_{101}=0.45 \mathrm{~d} L / \mathrm{d} t, \quad G_{110}=0.5 \mathrm{~d} W / \mathrm{d} t
$$

即ち, 単位時間当たりのリゾチーム結晶の縦及び横方向 の長さの変化を測定すればよい. これまで,リゾチーム の正方晶系結晶の2種類の結晶面の成長速度は非常に詳 細に調べられており，溶質濃度， $\mathrm{pH}$ 等溶液状態に強く 依存する事が報告されている ${ }^{17,18)}$.

\section{3. 結果と考察}

\section{1 自然結晶成長速度の見積もり}

光圧条件下に招ける結晶成長挙動との比較検討を行う ため，まずは同一のサンプル溶液を用いた自然結晶成長 挙動を観察し, 結晶各面の成長速度を式(1)に従って見 積もった。成長速度は同一実験を10回繰り返し行い，そ こから得られた值の平均值を算出した. Fig. 2(b)におけ るL及びWの変化を5分ごとに測定し, 見積もった成長速 度の経時変化をFig. 4 に示す。5分ごとに算出した平均 成長速度であるため, Fig. 4 での5分での測定結果は2.5 分としてプロットされている。

Fig. 4 より $G_{101}$ 及び $G_{110}$ は共にほぼ一定に変化している ことがわかる。 この時10サンプルの平均速度はそれぞれ $G_{101}$ が3. $3 \mathrm{~nm} / \mathrm{s}, G_{110}$ が $2.4 \mathrm{~nm} / \mathrm{s}$ と算出された. ここで注 目すべき点は本実験で使用したサンプルの条件下では自 然結晶成長に拈いて常に $G_{101}$ が $G_{110}$ よりも大きな值を示 すことである。上述のように, 両結晶面の成長速度は溶

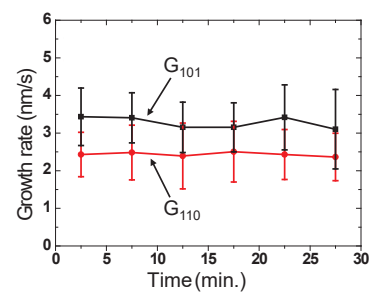

\begin{tabular}{ccc}
\hline $\begin{array}{c}\text { Time } \\
(\mathrm{min})\end{array}$ & $\begin{array}{c}\mathrm{G}_{101} \pm \mathrm{SD} \\
(\mathrm{nm} / \mathrm{s})\end{array}$ & $\begin{array}{c}\mathrm{G}_{110} \pm \mathrm{SD} \\
(\mathrm{nm} / \mathrm{s})\end{array}$ \\
\hline 2.5 & $3.4 \pm 0.77$ & $2.4 \pm 0.59$ \\
7.5 & $3.4 \pm 0.66$ & $2.5 \pm 0.73$ \\
12.5 & $3.2 \pm 0.67$ & $2.4 \pm 0.87$ \\
17.5 & $3.2 \pm 0.65$ & $2.5 \pm 0.81$ \\
22.5 & $3.4 \pm 0.86$ & $2.4 \pm 0.66$ \\
27.5 & $3.1 \pm 1.1$ & $2.4 \pm 0.63$ \\
\hline
\end{tabular}

Fig. 4 Temporal change in $G_{101}$ and $G_{110}$ estimated in spontaneous crystal growth for $30 \mathrm{~min}$. SD: Standard deviation.
液内のタンパク質の濃度に非常に敏感であることが知ら れており，本実験で使用した塩濃度下では広いタンパク 質の濃度領域において $G_{101}$ が優勢となり，タンパク質濃 度が極めて高い場合にのみ $G_{101}$ と $G_{110}$ の大小が入れ替わ ることが報告されている。

\section{2 光圧下での結晶成長挙動}

光圧により誘起されたリゾチームの結晶成長挙動を観 察し，各面の結晶成長速度を見積もった。結晶成長速度 は自然結晶成長の場合と同様5分に1度結晶の $L$ 及び $W の$ サイズ変化を測定し式1から算出した。以前のレーザー

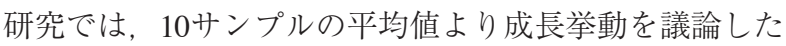
が12), その後研究が進むにつれ, 結晶成長速度の変化様 式は大きく2種類 (Case1，2)に分類されることが分かっ た(Fig. 5)。ここでCase1はレーザー照射を行った30分 間, 結晶成長速度が自然結晶成長の場合に比べ $G_{101}$ 及び $G_{110}$ ともに常に強く抑制され且つ一定に変化する場合, またCase2はレーザー照射10分程度まではCase1と同様に 変化し，その後急激な結晶成長速度の上昇が観察された 場合を指す。因みに結晶成長速度実験を行った 10 サンプ ルは必ずどちらかに分類され，Case1とCase2は約7:3の 割合で観察された。

Fig. 5(a)における点線は自然結晶成長での $G_{101}$ (上線) 及び $G_{110}$ (下線)を示している. 双方のCaseに共通の特徴 としては，レーザー照射初期に成長速度の著しい抑制が 観察されることである。一方，著者らの別の関連実験に おいて, リゾチーム濃度はレーザー照射に伴い集光点の 周辺ミリメートルの範囲で単調に増加することを確認し ている。にもかかわらず, Case1ではレーザー照射中に 常に強い成長速度の抑制が観察される。この結晶成長速 度の抑制原因として最初に思い浮かべるのが，レーザー 照射による温度上昇であろう。勿論, 温度上昇は成長速 度の抑制因子の一因子であることは間違いないが，著者 らの種々温度条件における実験結果と, 上述の集光点で の温度上昇(5度)から考察すると, 結晶成長速度抑制に
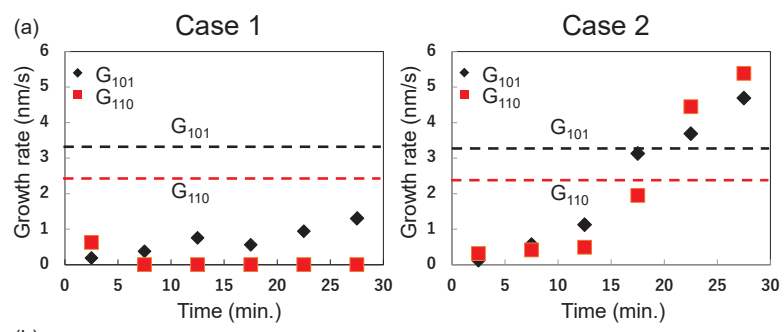

(b)
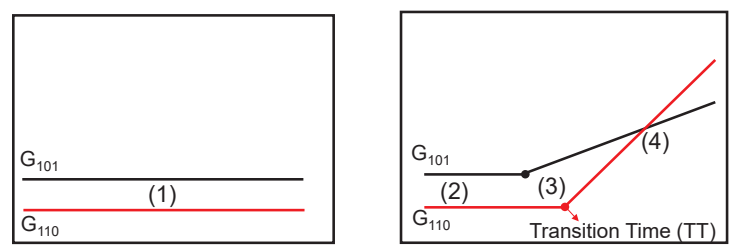

Fig. 5 (a) Representative example for two types of crystal growth behavior under laser trapping condition and (b) schematics of their temporal change in Case 1 and Case 2. 
対する温度上昇の効果は限定的であると考えている。す なわち, 結晶成長を抑制する他の要因を考察する必要が

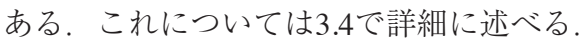

\section{3 結晶成長速度のレーザー偏光方向依存性}

光圧条件下の結晶成長速度に対するレーザー偏光方 向依存性について定量的に調べるため，2種類の結晶成 長様式Case1及びCase2をFig. 5(b)のように模式的に表 した。 以下，周辺のタンパク質の濃度変化に対してょ

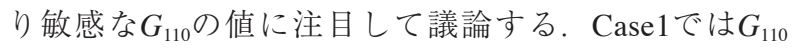
は自然結晶成長に比べ大きく抑制され(約一桁), 且つ レーザー照射30分間の間ほぼ一定值を示している (Fig. 5(b) (1)). この時, 30分間の $G_{110}$ の平均值を2つ のレーザーの偏光方向に対して計算した。 ここでレー ザーの偏光方向が(110)面に対して垂直な場合の成長速 度を $G_{110}(\mathrm{~V})$, 平行な場合を $G_{110}(\mathrm{P})$ と表記すると (Fig. 3 左上図参照), $G_{110}(\mathrm{~V})$ が $0.24 \mathrm{~nm} / \mathrm{s}, G_{110}(\mathrm{P})$ が $0.37 \mathrm{~nm} / \mathrm{s}$ と見積もられた. 即ち, $G_{110}(\mathrm{P})$ の方が $G_{110}(\mathrm{~V})$ に比 ベ1.5倍も速い. 勿論, レーザー強度, 集光点の位置は 全く同じであるため, 光圧捕捉力もレーザーによる温 度上昇の影響も全く同じである。にもかかわらずこの ようなレーザー偏光依存性が観察されたことは大変興 味深い.

次に, Case2の場合について考察する. Case2の場合 もCase1と同様, レーザー照射初期には非常に強い成長 速度の抑制が観察される(Fig. 5(b) (2))。この時, $G_{110}$ $(\mathrm{V})$ は $0.22 \mathrm{~nm} / \mathrm{s}, G_{110}(\mathrm{P})$ は $0.36 \mathrm{~nm} / \mathrm{s}$ 見積もられ, Case1 とほほ同一の值を示し且つ同様のレーザー偏光方向依 存性が観察された。この結果は，Case1における抑制と Case2のレーザー照射初期にみられる抑制が同等である ことを強く示唆している. その後続けてレーザーを照 射すると，Case2の成長挙動はCase1の場合とは大きく 異なってくる。レーザーを照射して10分程度 (時間は大 きく分散する) 経過すると $G_{110}$ が急激に上昇し始める (Fig. 5 (b) (3))。この時 $G_{110}$ は $G_{101}$ に比べて上昇率が大き く，その結果として $G_{110}$ と $G_{101}$ が交差し，ある時間で $G_{101}$ と $G_{110}$ の大小が入れ替わる(Fig. 5(b) (4)). 上述のよ うにこれはリゾチーム濃度が極めて高いときに観察され る現象である。速度が急激に上昇する(Fig.5(b) (4)) とき の単位時間当たりの速度の変化率(ここでは加速度 $\left(\mathrm{nm} / \mathrm{s} / \mathrm{min}^{-1}\right)$ とする)を異なるレーザー偏光方向に 対して計算すると, $G_{110}(\mathrm{~V})$ が $0.29 \mathrm{~nm} / \mathrm{s} / \mathrm{min}^{-1}, G_{110}(\mathrm{P})$ が $0.40 \mathrm{~nm} / \mathrm{s} / \mathrm{min}^{-1}$ と見積もられる。この場合も, Case1 及びCase2のレーザー照射初期に見られた成長抑制の時 と同様のレーザー偏光方向依存性を示す。この結晶成 長速度及び加速度に対するレーザー偏光方向依存性は, レーザー光強度を約半分にし，全く同様の実験を行っ た場合にも同じく観察された。 以上のように，結晶成 長速度及び加速度にレーザーの偏光方向依存性が観察 されたことから，上述した高濃度クラスター集合体内 の分子・クラスターの配列に異方性があることを強く 示唆している.
3.4 光圧による巨大高濃度クラスター集合体の形成 メカニズム

ここでは緒言でも少し触れた光圧による巨大高濃度ク ラスター集合体の形成メカニズムについて簡単に述べ る。著者らが本実験で用いたリゾチーム緩衝溶液の過飽 和度数は3.2程度と見積もられる ${ }^{19)}$ 。即ち, 実験に使用 した溶液は，飽和濃度に比べて3倍以上のリゾチームが 溶解した高い過飽和状態にある事を意味する。このよう な高過飽和溶液中では分子は溶質と溶媒が分子間相互作 用によってクラスターを形成することが知られており， 液状クラスターまたは結晶前駆体クラスターと呼ばれこ れまで多くの研究者によって報告されている ${ }^{20,211}$.

一方, 光圧捕捉力は対象物の体積に比例して大きくな り，またその屈折率が高くなるほど強くなる。よって, 本実験では分子単体よりもむしろ液状クラスターの方が 主たる捕捉対象物になると考えられる。これまでの研究 結果から, リゾチームの液状クラスターは数十ナノメー トル程度であると考えられるが，依然集光点の大きさに 比べてはるかに小さく，故に安定な捕捉は困難である.

しかしながら，一度液状クラスターが集光点内に捕捉さ れると, わずかながら光圧ポテンシャルが生じ, 次のク ラスターに対する捕捉力は大きくなる。 その結果, クラ スターは集光点内に連続的に捕捉され, 光圧ポテンシャ ルは深くなり，集光点内の濃度はそのポテンシャルの深 さに対して指数関数的に上昇していく．集光点における クラスター濃度が十分に上昇しある濃度に達すると，液 液相分離が誘起され局所的に安定な液状中間状態が形成 される。この中間状態はその高い安定性故に周辺の溶 質・溶媒を取り込みながら集光点の外側へと成長してい く。このようにして巨大高濃度クラスター集合体が形成 する。著者らは別の実験結果よりこのクラスター集合体 は最終的にはミリメートルオーダーにまで成長すると考 察している.

3.5 光圧によるリゾチーム結晶成長のメカニズム

光圧によるタンパク質結晶成長メカニズムの概略図を Fig. 6 に示す。最初に, Case1及びCase2の初期に観察され た強い結晶成長の抑制と3.4に述べた巨大高濃度クラス ター集合体との関係について述べる，上述のように，強 い結晶成長の抑制は温度だけでは説明できない。 そこで, 著者らは下記のような抑制メカニズムを提案している.

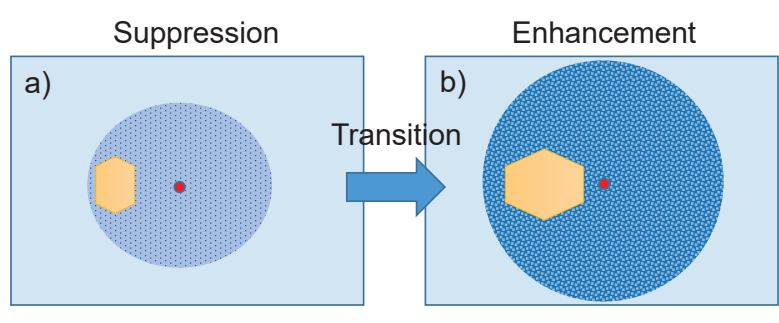

Domain 1

Domain 2

Fig. 6 Schematic illustration of the formation and transition of two types of HEWL cluster domains, showing suppression and enhancement of crystal growth. 
まず，高濃度クラスター集合体が非常に速い速度で(5分 まで)生成し，ターゲットとなる結晶を覆い尽くす (Fig. 6(a))。この時, そのクラスター集合体の高い安定 性から, リゾチーム分子の結晶への移動が妨げられ, 結 晶成長が抑制される，結晶成長がレーザーの偏光方向に 対して強く依存していることから, 高濃度クラスター集 合体内の分子・クラスターはレーザーの偏光方向に沿っ て配列する。これは，極めて興味深い実験結果であり， ミリメートルサイズの高濃度クラスター集合体内の分 子・クラスター配列を, わずか 1 ミクロン程度の集光点 での偏光によって操作することが可能であることを示し ている。この偏光依存性は集光点を別の位置に変えても 同様に観察されることも分かっており，著者らが提案し たメカニズムを強く支持している。これらの結果から， 強い結晶成長の抑制は，その集合体内の分子・クラス ターの回転，並進運動が妨げられたことによるクラス ター集合体の高い堅牢性によるものであると考えられ る. また，レーザーの偏光方向に従った分子・クラス ターの配列と (110) 面の分子配列の相対配置により, レーザー偏光方向依存性が観察されたと考えられる。す なわち, レーザーの偏光方向を(110) 面に対して平行に 設定した場合の分子・クラスター配列のほうが, 垂直な 場合に比べて、結晶成長にとってより好ましいと考察で きる。

次にCase2に観察される急激な成長速度上昇について 考える. 成長速度を上昇させる最も有力な駆動力は濃度 上昇である。よって，下記のような成長機構を提案して いる.Case1で生成した集合体の集光点での濃度は, レーザーを照射し続けることにより上昇し続ける。その 後, ある一定の濃度に達すると, 高い分子密度により内 部圧力が上昇し，リゾチーム分子・クラスターの部分的 な構造変化が誘起され, リゾチーム及び水分子の水素結 合ネットワークが変化する (Fig. 6(b)). 即ち, 分子・ク ラスターの濃度, 配列などが異なる別の高濃度クラス ター集合体へと転移する。Case2の初期に観察される結 晶成長の抑制とCase1の抑制の值がほぼ一致しているこ とからも，これら二つのクラスター集合体が連続的であ ると考えるのは合理的である。一方, Fig. 5(b) (4)にお いても同様のレーザー偏光方向依存性が観察されるた め, 転移後の集合体内の分子.クラスターの回転, 並進 運動もある程度妨げられてはいるが，その堅牢性は相対 的に低くなり，その高い濃度に起因して結晶成長速度は 上昇する。これらの結果から, 結晶成長様式が二つに分 かれる原因として照射時間を30分に設定していることが 挙げられ，本来はすべてCase2のように変化すると推察 された。実際，30分間に固定することなくレーザーを照 射すると，すべてのサンプルがCase2の成長様式を示し た.

\section{4. まとめ}

光圧によるニワトリ卵白リゾチーム結晶成長制御につ いて概説し、結晶成長がレーザーの偏光方向に強く依存
していることを示した，光圧をリゾチーム溶液に作用さ せることにより，1ミクロンの集光点から 3 桁も大きく広 がった高濃度クラスター集合体が形成し，その内部の分 子・クラスターがレーザーの偏光特性を反映した異方性 を示すことが分かった。ささらに，異方性や濃度が異な る2つのクラスター集合体が光圧により形成し，その異 なる化学的及び物理的特性を反映しながら結晶成長は制 御されることが分かった。

本結晶成長制御法は，原理的にはあらゆる化合物に適 用可能であるため，今後新しい結晶成長制御法として認 識されることを強く期待する。通常の結晶成長制御法で は系全体の溶液条件を調節することで系内にあるすべて の結晶がその対象となるが、本手法では単一結晶を成長 制御対象として選択することが可能である。今後は実験 の各種パラメータを最適化することで更なる精密な成長 制御にチャレンジしたい。

\section{謝 辞}

本研究の一部は, 台湾科技部研究計画(MOST1052113-M-009-025-), JSPS科研費JP16H06507（新学術領域 研究「光圧ナノ物質操作」)の助成のもとで実施された。

\section{参考文献}

1) P. Lebedev: Ann. Phys. 311 (1901) 433.

2) E. F. Nichols and G. F. Hull: Phys. Rev. 17 (1903) 26.

3) T. H. Maiman: Nature 187 (1960) 493.

4) A. Ashkin: Phys. Rev. Lett. 24 (1970) 156.

5) A. Ashkin, J. M. Dziedzic, J. E. Bjorkholm, and S. Chu: Opt. Lett. 11 (1986) 288.

6) K. Sasaki, M. Koshioka, and H. Masuhara: Appl. Spectrosc. 45 (1991) 1041

7) H. Misawa, N. Kitamura, and H. Masuhara: J. Am. Chem. Soc. 113 (1991) 7859.

8) K. Nakatani, H. Misawa, K. Sasaki, N. Kitamura, and H. Masuhara: J. Phys. Chem. 97 (1993) 1701.

9) T. Sugiyama, T. Adachi, and H. Masuhara: Chem. Lett. 36 (2007) 1480.

10) T. Sugiyama, T. Adachi, and H. Masuhara: Chem. Lett. 38 (2009) 482.

11) K. Yuyama, T. Sugiyama, and H. Masuhara: J. Phys. Chem. Lett. 1 (2010) 1321.

12）杉山 輝樹, 柚山 健一, 増原 宏：レーザー研究 42 (2014) 756.

13) J.-R. Tu, K. Yuyama, H. Masuhara, and T. Sugiyama: Cryst. Growth Des. 15 (2015) 4760.

14) J.-R. Tu, A. Miura, K. Yuyama, H. Masuhara, and T. Sugiyama: Cryst. Growth Des. 14 (2014) 15.

15) S. Ito, T. Sugiyama, N. Toitani, G. Katayama, and H. Miyasaka: J. Phys. Chem. B 111 (2007) 2365.

16) S. D. Durbin and G. Feher: J. Cryst. Growth 76 (1986) 583.

17) S. Gorti, J. Konnert, E. L. Forsythe, and M. L. Pusey: Cryst. Growth Des. 5 (2005) 535.

18) S. Gorti, E. L. Forsythe, and M. L. Pusey: Cryst. Growth Des. 4 (2004) 691.

19) E. Cacioppo and M. L. Pusey: J. Cryst. Growth 114 (1991) 286.

20) Y. Tsuboi, S. Tatsuya, M. Nishino, S. Masuda, K. Ishimori, and N. Kitamura: Appl. Surf. Sci. 255 (2009) 9906.

21) S. Chattopadhyay, D. Erdemir, J. M. B. Evans, J. Ilavsky, H. Amenitsch, C. U. Segre, and A. S. Myerson: Cryst. Growth Des. 5 (2005) 523. 